\title{
Production and Investigation of New Cast Aluminium Alloy with Lithium Addition
}

\author{
Izdelava in preiskava nove livarske aluminijeve zlitine \\ z dodatkom litija
}

\author{
Bastri Zeka, Boštjan Markoli, Primož Mrvar, Blaž Leskovar, Mitja Petrič* \\ University of Ljubljana, Faculty of Natural Sciences and Engineering, Department of Materials and Metallurgy, Aškerčeva 12, \\ 1000 Ljubljana, Slovenia \\ * mitja.petric@omm.ntf.uni-lj.si
}

\begin{abstract}
Lithium additions to $\mathrm{Al}$ offer the promise of substantially reducing the weight of alloys, since each $1 \mathrm{wt}$. \% Li added to $\mathrm{Al}$ reduces density by $3 \%$ and increases elastic modulus. In the present work, the effect of 1.46 wt. \% Li addition to AlSi7Mg (containing 7.05 wt. \% Si and 0.35 wt. \% Mg) was studied. The alloy showed reduced density and higher hardness after natural ageing. Experimental work showed that microstructural and mechanical properties changed with Li addition. It was observed that 0.80 wt. \% Li addition resulted in formation of new phase AlLiSi which has a great effect to increase hardness of AlSi7Mg. According to Scanning Electron Microscope (SEM) and X-ray diffraction analysis it was confirmed that the addition of Li causes formation of different phases which are: $\alpha$-Al, $\beta$-Si and AlLiSi.
\end{abstract}

Key words: aluminium, ageing, microstructural constituents, precipitation, mechanical properties.

\section{Povzetek}

Dodatki litija (Li) aluminijevim zlitinam prispevajo k bistvenemu zmanjšanju teže zlitin, saj vsak dodani odstotek litija zmanjša gostoto za $3 \%$. Litij tudi povzroči povečanje elastičnega modula. $V$ delu je preučen dodatek 1.46 mas. \% litija livarski zlitini AlSi7Mg, ki vsebuje 7.05 mas. \% Si in 0.35 mas.\% Mg. Zlitina je pokazala zmanjšanje gostote in večjo trdoto po naravnem staranju. Rezultati so pokazali, da so se mikrostrukturne in mehanske lastnosti spreminjale $\mathrm{z}$ dodatkom Li. Izkazalo se je, da dodatek 0.80 mas. \% Li povzroči pojav nove faze AlLiSi, ki močno vpliva na povečanje trdote AlSi7Mg. Glede na rezultate vrstične elektronske mikroskopije (SEM) rentgensko difrakcijsko analizo (XRD) je bilo potrjeno, da dodatek Li povzroči nastanek različnih faz, ki so: $\alpha-\mathrm{Al}, \beta-\mathrm{Si}$ in AlLiSi.

Ključne besede: aluminij, staranje, mikrostrukturne sestavine, precipitacija, mehanske lastnosti. 


\section{Introduction}

Al-Li base alloys have low density, high elastic modulus and high strength properties which make these alloys attractive for aerospace applications. The high strength is produced by the process of precipitation hardening. The addition of elements can form incoherent dispersoid or semicoherent precipitates and change the microstructure and mechanical properties of alloys [1-5]. Al-Li alloys use in aircraft applications, where the weight savings effected by using these low-density alloys greatly reduce the vehicle fuel costs and increase performance of parts such as: Aircraft parts such as leading and trailing edges, access covers, seat tracks; military and space applications such as main wing box, centre fuselage, control surfaces are made by $\mathrm{Al}-\mathrm{Li}$ alloys. Al-Li alloys are used as substitute for conventional aluminium alloys in helicopters, rockets and satellite systems [5-8]. The precipitates of Al-Li alloys are in several metastable and stable phases which can be present in Al-Li alloys, depending on the alloying elements. The metastable precipitates in this section are $\delta^{\prime}\left(\mathrm{Al}_{3} \mathrm{Li}\right)$, while the stable phase discussed is $\delta$ (AlLi) [8]. The precipitation, in turn, depends upon chemistry, grain structure, and total thermomechanical history. In Al-Li alloys, the strengthening from Li additions is due to both solid solution strengthening and precipitation hardening [1-20]. The precipitation hardening is primarily due to the metastable strengthening phase, $\delta^{\prime}\left(\mathrm{Al}_{3} \mathrm{Li}\right)$, which forms spherical, coherent, and ordered precipitate particles having a cube-on-cube orientation relationship with the aluminium matrix [20-25]. At equilibrium, and at its simplest in binary Al-Li alloys, the only phases present are the aluminium-rich solid solution and the $\delta$ (AlLi) phase [25-30].

New aluminium cast alloy was produced and analysed with $\mathrm{Li}$ additions based on $\mathrm{AlSi} \mathrm{Mg}$ alloy with improved mechanical properties where characterisation of solidification path was determined with all microstructural constituents. In order to develop new alloys with $\mathrm{Li}$ addition was used an optic microscope and Scanning electron microscopy (SEM) Thermal analysis and differential scanning calorimetry in accordance with thermodynamic equilib- rium calculations were used to determine the solidification course. Also, XRD analyses and mechanical testing (hardness testing,) were performed.

\section{Experimental Work}

New aluminium cast alloy AlSi7MgLi was investigated experimentally. The thermodynamic calculations were performed with ThermoCalc software and the chemical compositions of alloys given in Table 1 were used in order to calculate phase diagrams of alloys. Samples were melted in an induction furnace in a graphite crucible and cast in a steel mould where simple thermal analysis was performed. After data acquisition their numerical data, cooling curves and their derivatives were plotted and characteristic temperatures determined. Differential scanning calorimetry was performed, and sample prepared for microstructural investigation with optic microscope and scanning electron microscope with EDS in order to determine the phases present in alloy AlSi7 Mg. Vickers Hardness test was used to determine mechanical properties in period of 30 days after casting.

Table 1: Chemical composition of alloy in wt. \%.

$\begin{array}{lllllllll}\text { Alloy } & \mathrm{Al} & \mathrm{Si} & \mathrm{Fe} & \mathrm{Cu} & \mathrm{Mg} & \mathrm{Zn} & \mathrm{Ti} & \mathrm{Li}\end{array}$

$\begin{array}{lllllllll} & \mathrm{AlSi} & & & & & & & \end{array}$

AlSi7MgLi Rest $\begin{array}{lllllll}7.05 & 0.10 & 0.05 & 0.36 & 0.02 & 0.09 & 0.80\end{array}$

\section{Results and Discussion}

Thermodynamic description of system AlSi7MgLi cast alloys was constructed using ThermoCalc software. From the chemical composition in Table 1 the solidification and equilibrium phases were calculated for experimental alloy. According to the thermodynamic equilibrium calculation we have predicted solidification of the primary $\alpha-\mathrm{Al}, \beta-\mathrm{Si}$, new phases (AlLiSi), $\mathrm{Mg}_{2} \mathrm{Si}$, iron bearing phase $\pi-\mathrm{AlMgFeSi}$ and $\beta$-AlFeSi. 

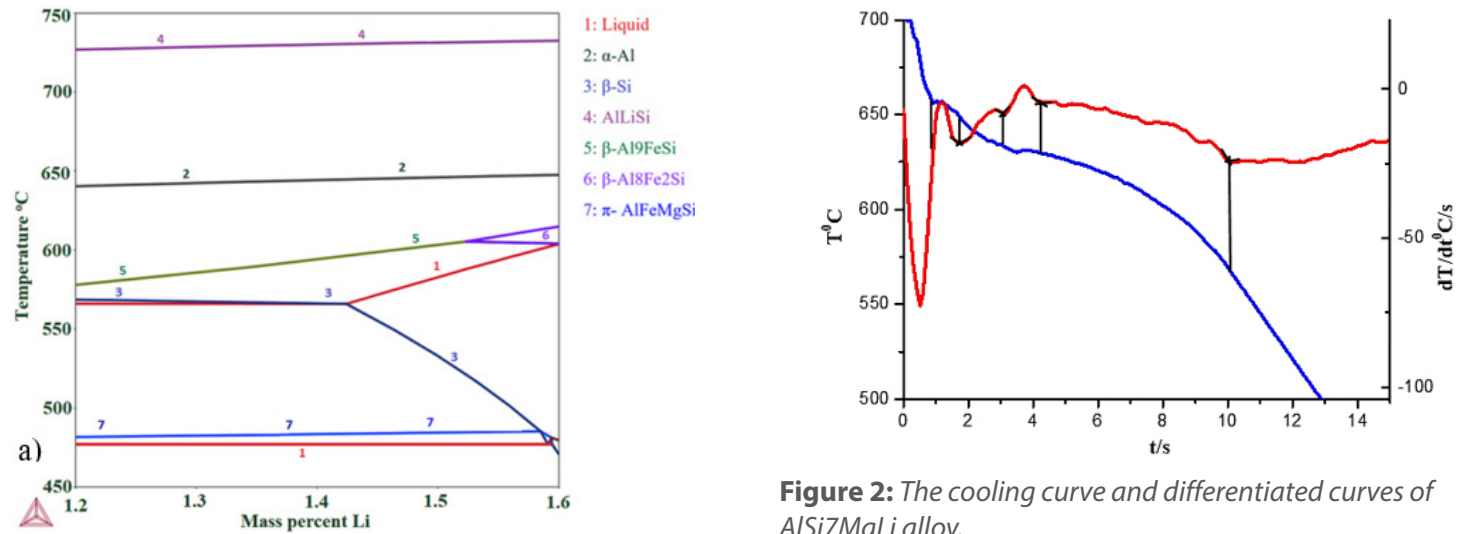

Figure 2: The cooling curve and differentiated curves of AlSiTMgLialloy.

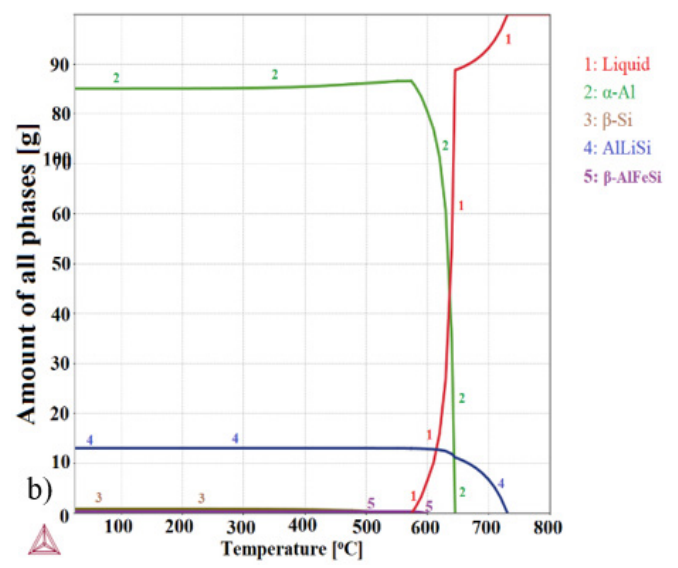

Figure 1: a) phase diagram of experimental alloy AISi7MgLi and b) amount of phases of alloy during solidification.

\section{Thermal Analysis}

Solidification process was analysed by thermal analysis on the samples cast in the steel mould and croning cell, each sample subjected to the solidification by cooling in the air. After the data acquisition their numerical and graphical processing with the marked temperatures of the phase transformations was performed. The cooling and differentiated curves of AlSi7Mg alloy with $\mathrm{Li}$ addition from casting temperature $730{ }^{\circ} \mathrm{C}$ in steel mould are shown in Figure 2. Diagram with cooling curves in the Figure 2 indicates interactive significant deviation in values of the characteristic temperatures of the solidification, acording to calculation and diargram of cooling curves at $730{ }^{\circ} \mathrm{C}$ with solidification start phases at $658{ }^{\circ} \mathrm{C}$. Solidification interval ended at $570{ }^{\circ} \mathrm{C}$.

The heating curve indicates melting start at $572{ }^{\circ} \mathrm{C}$ and the curve changes after $582.6^{\circ} \mathrm{C}$ and continued with evaluation of phase at $644.1^{\circ} \mathrm{C}$,
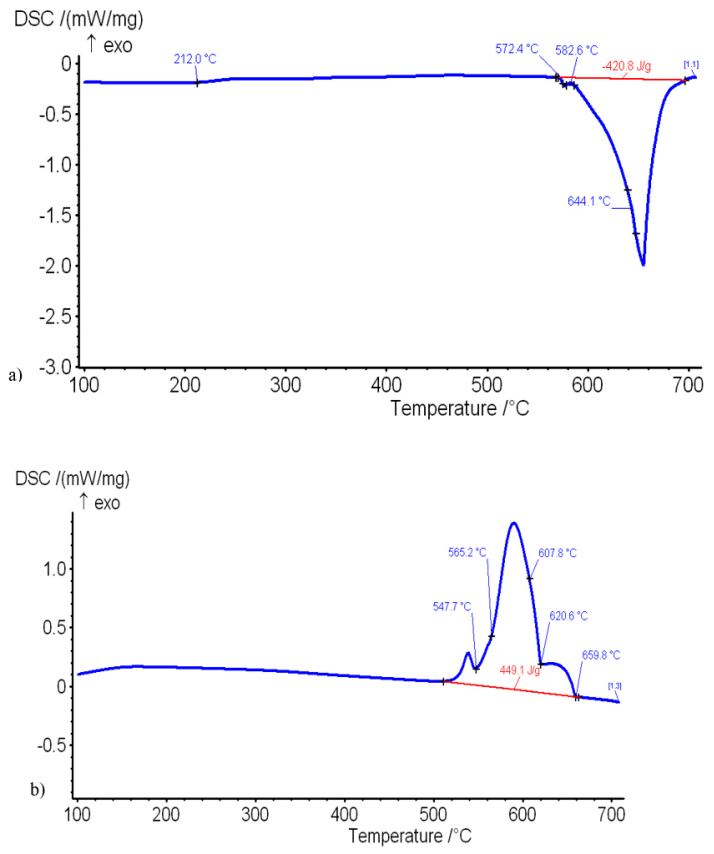

Figure 3: Heating DSC curve (a) and cooling DSC curve (b) of AlSi7MgLi alloy.

furthermore small peaks at $212{ }^{\circ} \mathrm{C}$ indicates precipitation process. Simultaneous thermal analysis was performed on the sample part from the sample poured in the steel mould, differential scanning calorimetry (DSC) resulted in diagrams of the heating and cooling curves shown in the figure 3-a and 3-b. Diagrams in the Figure 3 resulted in values of significant temperatures of the phase transformations. The temperature of the solidification start (liquidus temperature) at $659.8{ }^{\circ} \mathrm{C}$ with AlLiSi phase at $620.6^{\circ} \mathrm{C}$, the $\alpha-\mathrm{Al}+\mathrm{AlLiSi}$ should solidify according to thermocalc at $607.8^{\circ} \mathrm{C}$, followed by iron 

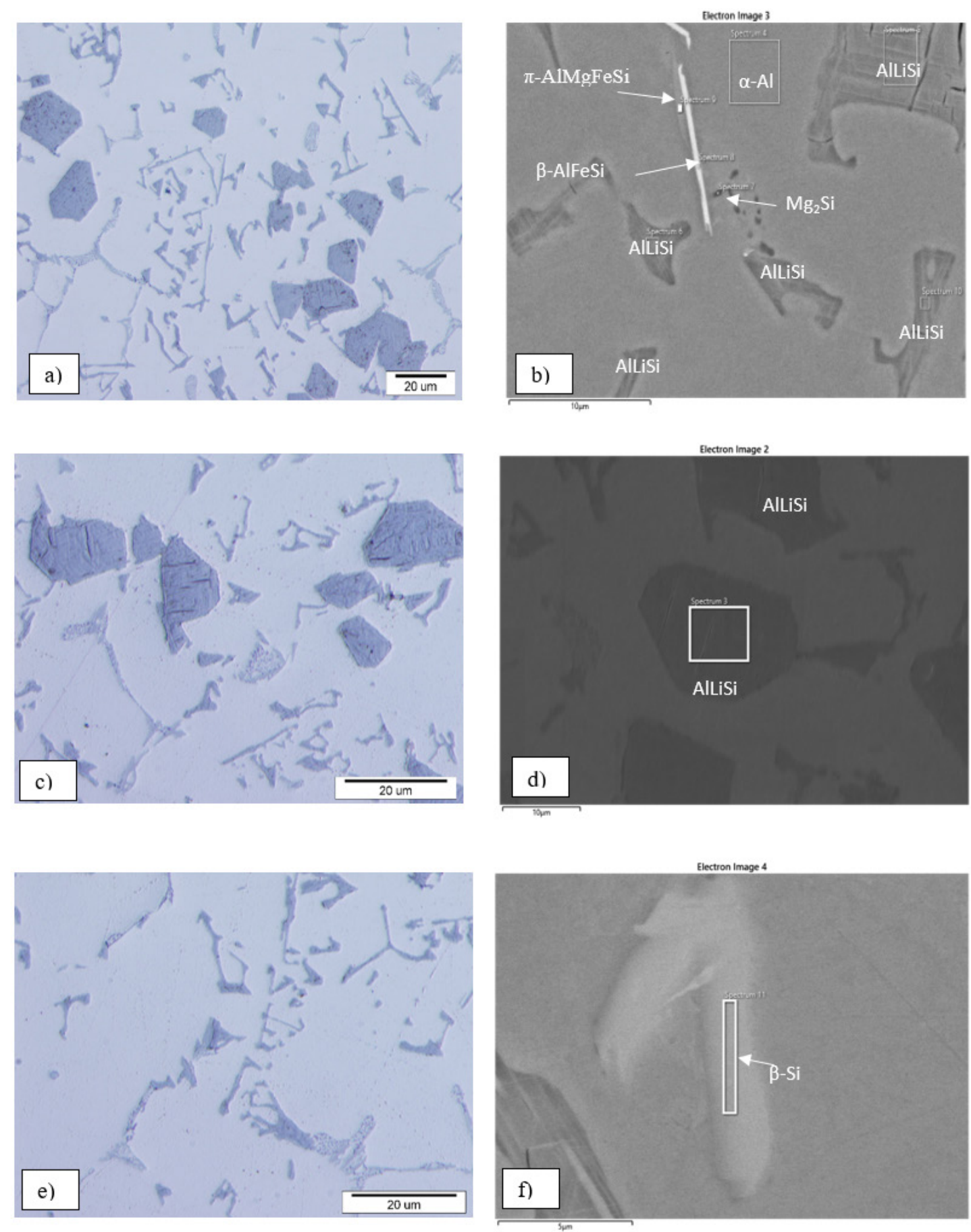

Figure 4: Optical $(a, c, e)$ and SEM micrographs $(b, d, f)$ of AISi7MgLi.

bearing phase $\beta$-AlFeSi at $565.2{ }^{\circ} \mathrm{C}, \beta$-Si and $\mathrm{Mg}_{2} \mathrm{Si}$ at $547.7^{\circ} \mathrm{C}$.

\section{Microstructure Analysis}

After analysis of solidification by thermal analysis technique samples were prepared for me- tallographic investigation. According to micrographs the microstructure consists of $\alpha$-Al phase, AlLiSi phase, $\pi-$ AlMgFeSi phase, $\mathrm{Mg}_{2} \mathrm{Si}$ which they are confirmed by EDS and XRD analysis and they presented in Figure 4b, 4d, 4f and Figure 5. With SEM we observed phases which 


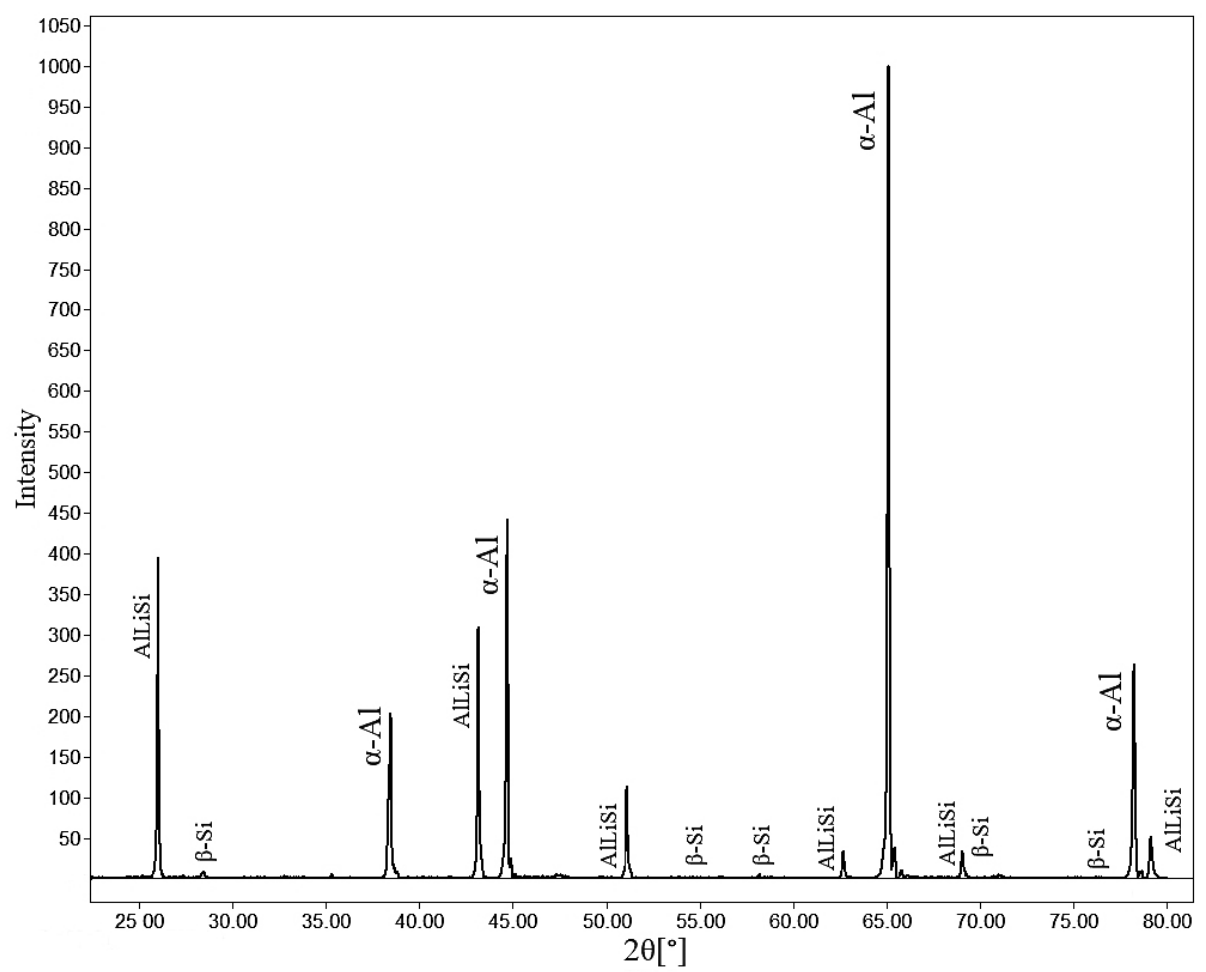

Figure 5: XRD pattern of AISiTMgLi alloy.

they are formed with Li addition. From Figure 4 it can be concluded that new phase AlLiSi appears. According to thermocalc calcalucaltion the elemental composition of phase present ascast state alloy the percentage of each element in the phase of AlLiSi is $33 \mathrm{wt} \%$, after analysis by SEM- EDS it was proved that AlSi contain lithium according to the thermodynamic calculation. Furthermore, microstructure in the alloy with $\mathrm{Li}$ addition consists from $\alpha-\mathrm{Al}, \beta-\mathrm{AlFeSi}$, $\pi-\mathrm{AlMgFeSi}$ and $\mathrm{Mg}_{2} \mathrm{Si}$. With XRD analysis we observed phases which they are formed with $\mathrm{Li}$ addition. From Figure 5 we confirm the formations of alpha $\alpha-\mathrm{Al}$, AlLiSi phases and $\beta$-Si.

\section{Mechanical Properties}

The samples were age-hardened for 30 days where 8 micro hardness measurements were performed at room temperature and average values were calculated.

Hardness test analysis for sample AlSi7Mg for first measurement was 66 HV. During 2-4 measurements, values showed a linear increase of hardness from $66 \mathrm{HV}-73 \mathrm{HV}$. It can be concluded that peak hardness was achieved after 7 days.

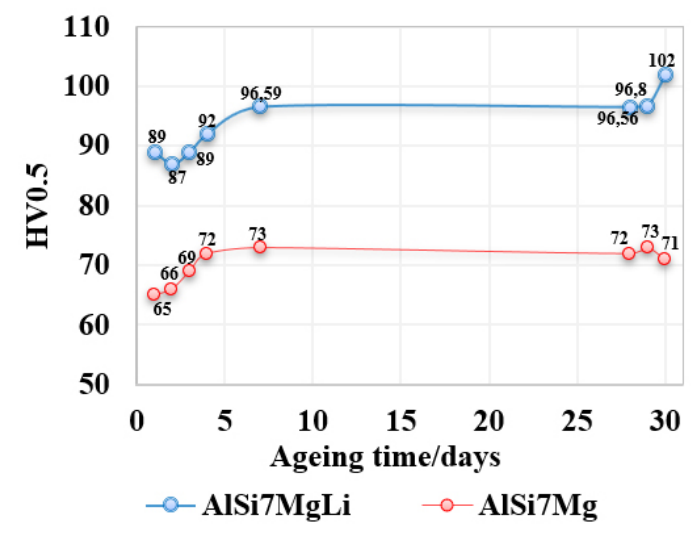

Figure 6: presents graph of hardness for natural ageing of AlSi7Mg and AISiTMgLi.

Hardness test analysis for sample AlSi7MgLi showed the hardness for first day was $89 \mathrm{HV}$ as cast state. After 24 hours of ageing, the hardness of sample dropped until $87 \mathrm{HV}$. After 2 to 7 days hardness of AlSi7MgLi alloy increased gradually from $87 \mathrm{HV}$ to $96 \mathrm{HV}$ where plateau is reached at $96 \mathrm{HV}$. It can be concluded that peak of hardness was achieved after 30 days at $102 \mathrm{HV}$. Our research showed that value of 
hardness increased during 30 days of ageing time from $65-73$ at AlSi7Mg whereas at AlSi7Mg with Li addition from 89-102 HV. According to results of both alloys, the Li addition to AlSi7Mg has great influence on increasing of hardness compared to AlSi7Mg.

\section{Conclusion}

New alloy with Li addition to AlSi7Mg alloy was studied. For this purpose $1.46 \mathrm{wt}$ \% Li was added to designed AlSi7MgLi alloy containing 0.36 wt. \% Mg and 7.05 wt. \% Si. It was found that $\mathrm{Li}$ combination with $\mathrm{AlSi} \mathrm{Mg}$ resulted on different solidification, development of new microstructure and creation of new phase AlLiSi. $\mathrm{Li}$ has influence to increase the mechanical properties in as cast state to AISi7Mg. SEM/ EDS and XRD analysis revealed that the addition of $\mathrm{Li}$ promotes the formation of new phase $\alpha-\mathrm{Al}$, $\beta$-Si and AlLiSi.

\section{References}

[1] Prasad, E.N., Gokhale, A., Wanhill, R.J.H. (2014): Aluminium-Lithium Alloys. Butterworth-Heinemann: Oxford, pp. 99-103.

[2] Polmear, I., StJohn D., Nie J.F., Qian M. (2017): Light Alloys-Metallurgy of the Light Metals. Butterworth-Heinemann: Oxford, pp. 55-110.

[3] Brown, J.R. (1999): Foseco non-ferrous foundryman's handbook. Butterworth-Heinemann: Oxford, $288 \mathrm{p}$.

[4] ASM Metals Handbook, (1990): Vol 02, Properties and Selection: Nonferrous Alloys and Special-Purpose Materials. ASM Internationl, pp. 250-300.

[5] Polmear, I. (2006): Light Alloys; From Traditional Alloys to Nanocrystals. Butterworth-Heinemann: Oxford, pp. 55-150.

[6] Backerud, L., Chai G., Tamminen J. (1990): Solidification characteristics of aluminium alloys. American Foundry Society, pp. 52-80.

[7] Polmear, I.J., Ringer, S.P. (2000): Evolution and control of microstructure in aged aluminium alloys. Journal of Japan Institute of Light Metals, 50, pp. 633-642.

[8] Polmear, IJ. (1999): Control of precipitation processes and properties in aged aluminium alloys by microalloying. Materials Forum, pp. 23-117.
[9] Baker, C., Gregson P.J., Harris, S.J., Peel, C.J. (1986): Aluminium-Lithium Alloys III. In: Proceedings 3rd International Conference on Aluminum-Lithium Alloys. The Institute of Metals: London, UK, pp. 509-515.

[10] Bagaryatsky, Y.A. (1952): Deformation behaviour of the AlMg4.5Cu0.5 type alloy sheet. Dokl Akad., 87, pp. 559-562.

[11] Adam, C.M. (1981): Aluminium-Lithium Alloys. AIME, New York: NY, pp. 37-48.

[12] Anyalebechi, P.N. (1995): Analysis of the effects of alloying elements on hydrogen solubility inliquid aluminum alloys. Scripta Metallurgica Materialla, 33(8), pp. 1209-1216.

[13] Ashton, R.F., Thompson, D.S., Starke Jr., E.A., Lin, F.S. (1986): Processing Al-Li-Cu-(Mg) alloys. In: Aluminium-Lithium Alloys III., Baker, C., Gregson, P.J., Harris, S.J., Peel, C.J. (eds.). The Institute of Metals: London, UK, pp. 66-77.

[14] Averill, W.A., Olsen, D.L., Matlock, D.K., Edwards, G.R. (1981): Lithium reactivity and containment. In: Proceedings of the First International Aluminium-Lithium Conference, Sanders, T.H., Starke, E.A. (eds.). The Metallurgical Society of AIME: Warrandale, PA, pp. 9-28.

[15] Binczeveki, G. (1986): Producing aluminium-lithium ingot encased in outer metal cladding. Light Met., Age June, pp. 31-36.

[16] Birch, M.E.J. (1986): Grain refining of aluminium-lithium based alloys with titanium boron aluminium. In: Aluminium-Lithium Alloys III, Baker, C., Gregson, P.J., Harris, S.J., Peel, C.J (eds.). The Institute of Metals: London, UK, pp. 152-158.

[17] Birch, M.E.J., Cowell, A.J. (1987): Titanium-carbon-aluminium: a novel grain refiner for aluminium-lithium alloys. In: Proceedings of the Fourth International Conference on Aluminium-Lithium Alloys, Champier, G., Dubost, B., Miannay, D., Sabetay, L. (eds.). J. Phys., Colloque, 48 (C3), p. 108.

[18] Bretz, P.E. (1987): Alithalites alloy development and production. In: Proceedings of the Fourth International Conference on Aluminium-Lithium Alloys, Champier, G., Dubost, B., Miannay, D., Sabetay, L. (eds.). J. Phys, pp. 25-31.

[19] Bretz, P.E., Gilliland, R.G. (1987): The intensive development programme that produced aluminium-lithium alloys. Light Met., Age April, pp. 5-12.

[20] Cassada, W.A., Shiflet, G.J., Starke, E.A. (1986): The effect of Germanium on the precipitation and deformation behaviour of Al-2Li alloys. Acta Metallurgica, 34(3), pp. 367-378. 
[21] Chakravorty, C.R., Singh, V., Gokhale, A.A. (1987): Melting and casting of aluminium-lithium alloys. In: Proceedings of the $36^{\text {th }}$ Annual Convention of Institute of Indian Foundrymen (IIF), The Institute of Indian Foundrymen: Calcutta, India, pp. 135-140.

[22] Colvin, G.N., Tak, J.H., Veeck, S.J. (1988): An investment cast Al-Li alloy HTC 321. In: Aluminium-Lithium Alloys: Design, Development and Application Update, Kar, R.J., Agarwal, S.P., Quist, W.E. (eds.). ASM International: Metals Park, OH, pp. 453-465.

[23] De Ross, A.B., Mondolfo, L.F. (1980): Metallurgical aspects of casting aluminium alloys. In: Aluminium Transformation Technology, Pampilo, C.A., Biloni, H., Embury, D.E. (eds.). ASM: Metals Park, OH, pp. 81-140.

[24] Dinsdale, K., Harris, S.J., Noble, B. (1981): Relationship between microstructure and mechanical properties of aluminium-lithium-magnesium alloys. In: Aluminium-Lithium Alloys, Proceedings of the First International Aluminium-Lithium Conference, Sanders, T.H., Starke, E.A. (eds.). The Metallurgical Society of AIME: Warrendale, PA, pp. 101-118.
[25] Divecha, A.P., Karmarkar, S.D. (1981): Casting problems specific to aluminium-lithium alloys. In: Aluminium-Lithium Alloys I, Sanders, T.H., Starke, E.A. (eds.). AIME: New York, NY, pp. 49-62.

[26] Divecha, A.P., Karmarkar, S.D. (1986): The search for aluminium-lithium alloys. Advanced Materials \& Processes Incorporating Metal Progress, 10, pp. 75-79.

[27] Fedosov, A.S., Danilkin, V.A., Grigoryeva, A.A. (1992): Influence of lithium on balance between hydrogen and aluminium melts. Tsvetn. Met. 2, 61-63. Foote Mineral Co. Bulletin, 1984. Technical Data Bulletin, p. 101.

[28] Fridlyander, I.N., Bratukhin, A.G., Davydov, V.G. (1992): Soviet Al-Li alloys of aerospace application. In: 'Aluminium-Lithium', Volume 2, Conf. Proc. Sixth. International Aluminium-Lithium Conference, 1991, Peters, M., Winkler, P.J. (eds.). DGM Information gesellschaft, Verlag: Germany, pp. 35-42. 